\title{
PATENT POOLS AND THE DIRECTION OF INNOVATION - EVIDENCE FROM THE 19TH-CENTURY SEWING MACHINE INDUSTRY
}

\author{
Ryan L. Lampe \\ Petra Moser \\ Working Paper 17573 \\ http://www.nber.org/papers/w17573
NATIONAL BUREAU OF ECONOMIC RESEARCH
1050 Massachusetts Avenue
Cambridge, MA 02138
November 2011

The views expressed herein are those of the authors and do not necessarily reflect the views of the National Bureau of Economic Research.

NBER working papers are circulated for discussion and comment purposes. They have not been peerreviewed or been subject to the review by the NBER Board of Directors that accompanies official NBER publications.

(C) 2011 by Ryan L. Lampe and Petra Moser. All rights reserved. Short sections of text, not to exceed two paragraphs, may be quoted without explicit permission provided that full credit, including $\odot$ notice, is given to the source. 
Patent Pools and the Direction of Innovation - Evidence from the 19th-century Sewing Machine Industry

Ryan L. Lampe and Petra Moser

NBER Working Paper No. 17573

November 2011

JEL No. D4,K21,L10,L24,L4,N61,N81,O3

\begin{abstract}
Patent pools allow a group of firms to combine their patents as if they were a single firm. Theoretical models predict that pools encourage innovation in pool technologies, albeit at the cost of innovation in substitutes. Empirical evidence is scarce because modern pools are too recent to allow empirical analyses. This article examines data on patents and innovations by new firms for a historical pool in the sewing machine industry (1856-1877) to examine effects on innovation. Contrary to theoretical predictions, this analysis suggests that pools may discourage innovation in pool technologies and shift R\&D towards technologically inferior substitutes.
\end{abstract}

Ryan L. Lampe

DePaul University

1 East Jackson Blvd

Suite 6200

Chicago, IL 60604

rlampe@depaul.edu

Petra Moser

Department of Economics

Stanford University

579 Serra Mall

Stanford, CA 94305-6072

and NBER

pmoser@stanford.edu 


\title{
PATENT POOLS AND THE DIRECTION OF INNOVATION - EVIDENCE FROM THE $19^{\mathrm{TH}}$ CENTURY SEWING MACHINE INDUSTRY RyAn LAMPE AND PETRA MOSER*
}

\begin{abstract}
Patent pools allow a group of firms to combine their patents as if they were a single firm. Theoretical models predict that pools encourage innovation in pool technologies, albeit at the cost of innovation in substitutes. Empirical evidence is scarce because modern pools are too recent to allow empirical analyses. This article examines data on patents and innovations by new firms for a historical pool in the sewing machine industry (1856-1877) to examine effects on innovation. Contrary to theoretical predictions, this analysis suggests that pools may discourage innovation in pool technologies and shift R\&D towards technologically inferior substitutes.
\end{abstract}

Patent pools, which allow competing firms to combine their patents as if they are a single firm, have become one of the most prominent mechanisms to address problems with the current patent system. For example, pools have been proposed as a means to prevent litigation over tablet computers, smart phones, and video compression technologies, and are expected to facilitate licensing and encourage scientific progress in molecular diagnostic testing for breast cancer and treatments for HIV, cholera, and malaria. ${ }^{1}$

Enthusiasm for patent pools is fueled by the expectation that pools encourage the adoption of new technologies and raise expected profits from R\&D. For example, pools are expected to reduce litigation risks and facilitate the production of new technologies when competing firms own blocking patents for complementary parts of the same technology and prevent each other from commercializing that technology (Shapiro, 2001; Lerner and Tirole,

\footnotetext{
* Lampe: Department of Economics, DePaul University, Chicago, IL 60604, rlampe @ depaul.edu; Moser: Department of Economics, Stanford University, Stanford, CA 94305, pmoser@ stanford.edu. We wish to thank the Wisconsin State Historical Society for granting access to the Singer Archives, and Nick Bloom, Tim Bresnahan, Uli Dorazelski, Eric Hilt, Mark Lemley, Michael Meurer, Anthony Niblett, Frédéric Panier, Tim Simcoe, Gavin Wright and seminar participants in Bonn, at the NBER, the Illinois Economics Association, and Stanford for helpful comments. Nicola Bianchi, Marina Kutyavina, and Owen Boochever provided excellent research assistance. ${ }^{1}$ For example, Google launched an open-source video format pool to counter MPEG LA's pool for the H.264 video coding standard. MPEG has also announced plans for a patent pool in diagnostic genetic tests. A Pool for Open Innovation against Neglected Tropical Diseases combines medicines to treat malaria, and UNITAID's Medicines Patent Pool aims to improve access to HIV treatments in developing countries.
} 
2004). Thus, courts have argued that "In a case involving blocking patents, such an arrangement is the only reasonable method for making the invention available to the public" (International Mfg. Co. v. Landon, 336 F.2d 723, 729 (9th Cir. 1964)). Pools that combine complementary patents are also expected to reduce license fees for outside firms as they avoid "royalty stacking," which occurs when multiple patents cover the same technology, and each patent owner individually charges license fees that are too high considering the optimal price for the complete product (Merges, 1999; Shapiro, 2001, p.134; Lerner and Tirole, 2004). ${ }^{2}$

As a result, antitrust authorities are generally supportive of pools that combine complementary patents without outside substitutes because they expect such pools to "provide pro-competitive benefits by integrating complementary technologies, reducing transaction costs, clearing blocking positions, and avoiding costly infringement litigation" (Department of Justice, 1995). ${ }^{3}$

A primary concern, however, is that pools of complementary patents may discourage innovation in substitutes for pool technologies, as they "unreasonably foreclose the non-included competing patents from use by manufacturers" (Department of Justice, 1999). Thus the creation of a pool of complementary patents is feared to put substitutes at a disadvantage, even if they are technologically superior to the pool technology because:

"including only one of several substitute patents in a pool 'risks foreclosing markets to competing patents outside the pool' because a licensee would not purchase both a pool license and a license for a substitute patent, even if that substitute were a superior technology" (Department of Justice and Federal Trade Commission, 2007).

\footnotetext{
${ }^{2}$ In contrast, pools that combine substitute patents may increase license fees (Lerner and Tirole, 2004).

${ }^{3}$ In the 1990s, the Department of Justice approved the MPEG-2 pool, the 3G platform and two DVD pools, which established technological standards for computers and DVD players (see Merges, 2001). These pools included "essential" patents for complementary technologies without substitutes outside of the pool. For (non-essential) complementary patents with substitutes, Quint (2009) predicts that pools reduce overall welfare if lower prices for pool patents reduce the profitability of outside patents.
} 
Empirical evidence on the effects of patent pools is, however, scarce, because modern pools are too recent to examine their effects on technical change and because modern technologies are generally too complex to allow researchers to clearly recognize substitutes. Thus, empirical analyses have focused on the determinants of participation and on the design of agreements to govern profit sharing and access to patented inventions (Lerner, Strojwas, and Tirole, 2006; Layne-Farrar and Lerner, 2011).

This paper uses data for the Sewing Machine Combination (1856-1877) to investigate the potential effects of a pool on the rate and direction of technical change. ${ }^{4}$ As the first patent pool in U.S. history, the sewing machine pool operated in the complete absence of regulation. ${ }^{5}$ This provides a particularly clean test of theoretical predictions, which typically assume the absence of government intervention (Shapiro, 2001; Lerner and Tirole, 2004; Dequiedt and Versaevel, 2007). The historical setting also makes it possible to observe the complete life cycle of an industry from the prototype stage to technical maturity. Another benefit is that sewing is simple enough to allow us to clearly identify substitutes for the pool technology, which is substantially more difficult for modern data.

Earlier work suggests that the creation of a pool may have reduced, rather than increased the rate of technical change in sewing machines (Lampe and Moser, 2010). Patenting declined after the creation of a pool, both in absolute levels and relative to other industries. Patenting also declined relative to Britain, which did not have a pool; British patents continued to increase

\footnotetext{
${ }^{4}$ The sewing machine industry played an important role in the technological development of the United States. Machine tools developed for the mass production of sewing machines were adopted by other industries, including car-making, as part of the American System of Manufacturing (Hounshell 1984, pp. 67-124). In 1890, sewing accounted for eight percent of GDP (Depew, 1968, p. 538).

${ }^{5}$ The first major antitust case was E. Bement \& Sons v. National Harrow Co. 186, U.S. 70, 91 (1902). National Harrow's had formed to end crippling litigation over float spring tooth harrows (used to soften top soil for cultivation). This pool grew to include 22 firms that covered over 90 percent of the market and required licensees to adhere to a uniform pricing scheme. The Supreme Court decided that the pool's licensing terms were lawful, arguing that the benefits it conferred - preventing litigation over patent scope and validity - outweighed the costs that price-fixing created for the industry.
} 
gradually throughout this period, while U.S. patents only increased again after the patent pool dissolved in 1877. Alternative measures of innovation confirm that the rate of technical change slowed after the pool had formed and increased again after it had dissolved.

But a simple application of models of vertical differentiation suggests that the creation of a pool may also affect the direction of technical change in an unexpected way: Specifically, the creation of a patent pool may encourage rather than discourage innovation in - technologically inferior - substitutes. Pools typically combine patents for the best available technologies (Shapiro, 2001; Gilbert, 2004), and - as a remedy for blocking patents - allow members to produce the highest quality product. This creates a market-niche for outside firms to enter with lower quality and less expensive substitutes, which increases the expected returns of R\&D to improve substitutes. ${ }^{6}$ Incentives for shifting innovation away from pool technologies towards lower quality substitutes may be particularly strong for pools that introduce differential license fees or increase litigation risks for outside firms; both mechanisms make it difficult for outsiders to compete with the pool technology.

In the sewing machine industry, four prominent firms - Singer, Wheeler \& Wilson, Grover \& Baker, and Elias Howe - agreed to pool their patents to end crippling litigation during the “sewing machine wars" (1851-1856, Bissell, 1999, p. 84). Their pool combined nine complementary patents that were necessary to build state-of-the-art sewing machines. Its key technology was the lockstitch (U.S. patent 4,750), an efficient and sturdy stitch mechanism,

\footnotetext{
${ }^{6}$ With price competition and consumers with identical tastes but different incomes, equilibria exist where both high and low quality products are offered (Gabszewicz and Thisse, 1979). If entrants can choose the quality of their product, some firms enter with high quality and others with low quality products to avoid price competition (Shaked and Sutton, 1982). Berry and Waldfogel (2010) find that market size increases the range of qualities in the restaurant industries, where quality is produced with variable costs, but not in the newspaper industry, where quality is produced with fixed costs, and average quality increases with market size. See Tirole (1998) for a concise presentation of key ideas.
} 
which continues to be used today. Its closest substitute, the chain stitch, was widely understood to be technologically inferior and "unsuitable for sewing purposes" (Flint et al., 1878, p. 425).

To measure changes in innovation for pool technologies and substitutes we compare changes in lockstitch and chain stitch patents per year after the pool formed with changes in other sewing machine patents. This difference-in-differences approach makes it possible to control for unobservable factors, such as changes in the demand for sewing machines, which may have encouraged invention in substitutes for the pool technology independently of the pool. Time fixed effects control for changes in patenting over time and subclass fixed effects control for differences in the propensity to patent across technologies.

Data include all 4,576 U.S. patents granted for sewing machines between 1845 and 1885 and - as an alternative measure of innovation - information on the technology choice of 170 new firms that entered the industry between 1849 and 1885 . To distinguish pool technologies from substitutes, we link U.S. patents and sewing machine models with technical information on sewing machines from manuals for collectors of antique sewing machines (Cooper, 1976; Bays, 2007).

Patent data indicate a dramatic shift towards substitutes after the pool had formed. Until 1856, a comparable number of lockstitch and chain stitch patents were granted each year. After the pool had formed, nearly twice as many patents were granted for the chain stitch compared with the lockstitch. Regressions that control for differences in the intensity to patent across technology classes and years imply a 6-fold increase in chain stitch patenting immediately after the creation of the pool. These results are robust to a broad range of alternative specifications, including controls for pre-existing time trends, for the quality of patented inventions, and for the count data nature of patents. 
A potential caveat to these results is that the change in patenting may reflect a change in the need for strategic patenting, rather than a true change in innovation. Specifically, if the creation of a pool reduces litigation risks for pool members and outside firms, it may reduce the need for strategic patenting in the pool technology. To address this issue we examine changes in the technology choice of new firms as an alternative measure of innovation. These data confirm that innovation shifted towards the technologically inferior substitute after the pool had formed, and only returned to focus on the pool technology after the pool had dissolved.

\section{The SEWING MACHINE PoOL, 1856-1877}

On 10 September 1846, the U.S. Patent Office granted patent No. 4,750 to Elias Howe for "a device for passing a second thread through a loop in the first," "the idea that made mechanical sewing a practical art" (Scientific American, Vol. 7 (1865), p. 264). Howe's patent was so broad that it covered practically any device to sew a lockstitch and other firms contested it almost immediately. The Circuit Court, however, upheld Howe's patent in 1852 (Scientific American, Vol. 13 (1852), p. 356), effectively enabling Howe to extract large amounts of license fees (Depew 1895, p. 526$){ }^{7}$ Similar to patent trolls today, Howe did not produce any machines, but began to extract $\$ 25$ per machine from producers, roughly one quarter of the average price of a machine (Cooper, 1976, p. 47). Firms that owned patents that were needed to build a commercially viable machine began to sue each other - creating one of the first patent wars - and the production of sewing machines came to a halt (Cooper, 1976, p. 41).

To resolve this early patent war, Howe and three dominant producers - Singer, Wheeler \& Wilson, and Grover \& Baker - agreed to pool nine complementary patents on October 24, 1856

\footnotetext{
${ }^{7}$ Also see Cooper, 1976, p. 28 and 41.
} 
(Albany Agreement, Singer Papers, Box 225). ${ }^{8}$ Taken together, these three firms accounted for 93 percent of output in $1856 .^{9}$

In addition to Howe's lockstitch, the pool included two other patents - equally broad - for technologies that manufacturers needed to build a high-quality sewing machine: Singer's patent U.S. 6,439 on the combination of a vertical needle with a horizontal sewing surface, and Wheeler \& Wilson's patent 12,116 on a "four-motion" mechanism to feed cloth to the needle. ${ }^{10}$ Although Howe's patent covered nearly every improvement in the lockstitch, it did not extend to the closest substitute, the chain stitch. Based on the "erroneous idea that the sewing machine must imitate the human hand and fingers" (Cooper, 1976, p. 11), the chain stitch was well understood to be inferior to the pool's technology. The single-thread chain stitch came easily undone (Jack, 1956, p. 114; Cooper, 1976, pp. 19-20), while the two-thread chain stitch was inefficient and produced a bulky seam (Cooper, 1976, p. 38). ${ }^{11}$

\section{A. Increasing litigation risks for outside firms}

Until the pool had formed, manufacturers who licensed Howe's lockstitch patent, could market slight modifications of existing machines (Depew, 1895, p. 529). For example, Isaac Singer was able to reverse-engineer a machine by Lerow and Blodgett within 11 days, and, with a few slight improvements, began to market and patent it as his own (Cooper, 1976, p. 30). After

\footnotetext{
${ }^{8}$ The creation of the pool appears to have been unanticipated: Contemporary newspapers, such as the New York Times, Chicago Tribune and Scientific American include no references to a pool before the Albany Agreement was announced. In fact, Grover \& Baker was only included because its President, Orlando Potter, suggested the idea of a pool (Cooper, 1976, p. 41).

${ }^{9}$ Singer had produced 5,136 machines between January 1853 and December 1856, Wheeler \& Wilson 4,936, and Grover \& Baker 5,787. By contrast, 13 remaining firms had produced fewer than 650 machines each by 1856 (Cooper, 1976, p.47).

${ }^{10}$ Anecdotal evidence suggests that inferior substitutes also existed for the four motion feeding mechanism (Knight, 1877, p. 2102), but - similar to modern technologies - it is impossible to uniquely identify invention in these substitutes.

${ }^{11}$ One of the pool members, Grover and Baker, produced a two-thread chain stitch; it exited the industry in 1875 (Cooper, 1976, p. 70). Early chain stitch machines, such as Thomas Saint's (British patent 1,764 in 1790) and Barthelemy Thimonnier's (France, 1830) were not commercialized (Cooper, 1976, p. 42).
} 
the pool formed, Singer and other members began to aggressively exclude competitors that they perceived to produce "offensive imitations" of the pool technology (Depew, 1895, p. 530).

Evidence from court records only measures cases that went to trial, and may therefore underestimate the real threat of litigation, but it is nevertheless suggestive. While the pool was active, it was a defendant in only 3 cases, but initiated 15 cases against outside firms (Lampe and Moser, 2010). ${ }^{12}$

The four firms also agreed to defend their patents as a group and established a litigation fund of $\$ 10,000$ (equivalent to 265,000 year $2010 \$$ using the consumer price index and 36.2 million $\$$ as a share of GDP), exceeding the annual sales of most small manufacturers (Cooper, 1976, p. 41). ${ }^{13}$

\section{B. Lower license fees for pool members}

Although the pool licensed its technology to any firm that did not copy its machines, ${ }^{14}$ and the pool did not interfere with licensees' choice of price or product quality (Depew, 1895, p. 530; Hounshell, 1984, p. 68) ${ }^{15}$ it created a significant gap between the licensing costs for members and outside firms, which may have reduced the ability of outside firms to compete with

\footnotetext{
${ }^{12}$ With the lockstitch patent secured in court, litigation focused on Wheeler and Wilson's patent (U.S, Patent 7,776) for a mechanism to feed cloth to the machine, with 13 of 14 cases initiated by the pool (data from final judgments in Westlaw's pre-1945 federal courts database). Patent data suggest that the pool may have also deterred innovation in this technology. Subclass 323 relates to the four-motion feed. While the pool was active between 1857-76, an average of 3.5 patents were issued in subclass 323 . After the pool dissolved, the average climbed to 8.4 patents per year between 1877-85. The pool's patent for a flat sewing surface may have been broad enough to deter entry without further litigation.

${ }^{13}$ Conversions based on Williamson (2010).

${ }^{14}$ Howe, who relied on license fees as his only source of revenue, demanded that the pool license to a minimum of 24 manufacturers (Cooper, 1976, p. 41). Although this goal was never reached, he managed to extract the equivalent of 30 million year 2010 dollars by the time his patent expired in 1867 (using Williamson's (2010) GDP deflator to convert Parton's (1867) estimate of $\$ 2$ million.)

${ }^{15}$ The pool licensee Willcox \& Gibbs, for example, only used the vertical needle and four-motion feed but rejected Howe's lockstitch (Cooper, 1976, p. 47). Regarding production quotas, the Albany Agreement stipulated that licensees should not sell more than 1,000 machines per year, but many licensees produced more machines. Ladd \& Webster, for example, sold 1,788 machines in 1859 (Cooper, 1976. p. 40).
} 
pool technologies. In 1856, the pool reduced Howe's license fees from $\$ 25$ to $\$ 5$ for members and $\$ 15$ for other firms (Bays, 2007, p. 15). In 1860, when Howe's patent first expired and was renewed for 7 years, fees dropped to $\$ 1$ for members and $\$ 7$ for other firms. ${ }^{16}$ In 1867 , when the U.S. Congress denied Howe a second extension, the pool abolished fees for members and lowered fees to $\$ 5$ for other firms. In 1870 fees for outsiders declined to $\$ 3$ (Vaughan, 1956, p. 41).

\section{The last pool patent expires in 1877}

When Howe's patent expired in 1867, the pool continued on the strength of patents for Wheeler \& Wilson's feeding mechanism and Singer's horizontal surface. Since the Albany Agreement did not include a grant back rule, which would have required pool members to offer any new patents first to the pool (Lerner, Strojwas, and Tirole, 2007), it dissolved when the last of the original nine patents - on Singer's horizontal surface - expired on May $8,1877 .^{17}$

\section{DATA}

Data on all U.S. patents for sewing machines between 1845 and 1885 serve as the main measure of innovation; data on the technology choice of new firms that entered the sewing machine industry serve as an alternative measure of innovation.

A. U.S. Patents for Sewing Machines, 1845-1885

\footnotetext{
${ }^{16}$ Under the Patent Act of 1836 (5 Stat. 117, 119, 5) patentees could petition the Commissioner of Patents for a 7year extension to the basic 14-year term. Second extensions required an Act of Congress, which Howe and Wheeler \& Wilson failed to obtain in 1867 and 1875, respectively (New York Times, January 26, 1875).

17 Theoretical predictions about the effects of "grant-back" rules are ambiguous. Grant backs may reduce incentives to innovate by requiring members to share expected profits from future inventions, but they also prevent hold-up by blocking patents (Lerner and Tirole, 2004; Lerner, Strojwas, and Tirole, 2007).
} 
Between 1845 and 1885, the U.S. Patent Office granted 4,576 U.S. patents in class 112: Sewing; these patents are recorded in the USPTO Patent Full-Text and Image Database. Class 112 is divided into 362 subclasses for patents issued, which on average produce 0.42 patents per year between 1845 and 1885. Sixteen subclasses are lockstitch inventions (112:181196); 9 subclasses are chain stitch inventions (112:173-175 and 197-202). ${ }^{18}$ Subclasses of lockstitch and chain stitch inventions produce 0.77 and 0.79 patents per year, respectively, between 1845 and $1885 .^{19}$ Grant years measure the timing of inventions. ${ }^{20}$

\section{B. Two alternative controls for the quality of patents}

To control for variation in the quality of patents, we collect data on the number of $20^{\text {th }}$ century patents that cite historical sewing machine patents. ${ }^{21}$ Data on citing patents after 1975 are available in the NBER patent data (Hall, Jaffe, and Trajtenberg, 2001). These data can, however, only capture citations 100 years after the initial patent, when it is likely to be obsolete. To close this gap, we create a search algorithm that picks out references to patent numbers in patent grants between 1920 and 1974. As a first cut, our search algorithm identifies 600 references to 467 unique patent numbers in class 112 . We check all references; 445 of them are

\footnotetext{
18 Three subclasses for machines that use multiple needles could be either chain stitch or lockstitch inventions (112:164-166). Another subclass (112:168) includes machines that can switch between stitch types; it produced 53 patents. Results are robust to different ways of assigning these subclasses.

${ }^{19}$ Three patents that were listed both as chain and lockstitch inventions $(21,089,18,880$, and 89,093), are included in both categories.

${ }^{20}$ In a random sample of 100 patents between 1873 and 1875 , the average sewing machine patent was granted 140 days after the application. This finding is consistent with Thomson's (1987, p. 435) observation that sewing machine patents were typically granted six months to a year after the application.

${ }^{21}$ Citations are the most frequently used measure of patent quality. Trajtenberg (1990) shows that patents for socially valuable innovations in Computed Tomography (CT) are cited more in later patents. In a data set of agricultural innovations in hybrid corn, citations are positively correlated with the size of innovations, measured by improvements in yields (Moser, Ohmstedt, and Rhode, 2011).
} 
patent citations to 359 unique sewing machine patents in class $112 .^{22}$ Including patent citations from the NBER data set, these data indicate that 618 patents - 14 percent of sewing machine patents between 1845 and 1885 - were cited by at least one patent after 1920 (Table 1).

An alternative measure of patent quality takes advantage of an independent selection of important patents by curators of the Smithsonian Institution. Until 1880, the USPTO required patentees to submit a model of their invention. On February 13, 1925, Congress appropriated $\$ 10,000$ to dispose of these models and offer them to the Smithsonian Institution (Brown, 1994, p. 6). Smithsonian curators then selected 751 patents that they considered most important; 708 of these patents were issued between 1845 and 1885 in class 112 (Cooper, 1976, p. 206, Table 1). ${ }^{23}$ Ten percent of patents granted during the pool period are cited, compared with 14 percent before and 17 percent after the pool.

\section{The technology choice of new firms, 1849-1885}

Data on the technology choice of entrants provide an alternative measure of innovation.

A total of 170 sewing machine manufacturers entered the sewing machine industry between 1849 and 1885 . For 146 of these firms, stitch types can be uniquely identified from archival sources. Photographs and technical notes in collectors' manuals (Cooper, 1976; Bays, 2007) and trade cards from the Smithsonian archives identify stitches for 111 machines. Knight's (1876) Dictionary of Mechanical Inventions records stitches for 29 machines. Product names that refer

\footnotetext{
${ }^{22}$ Without this check, the algorithm may falsely identify as citations references to patent numbers in a different context. For example, the algorithm identifies U.S. patent 1,462,243 for "an improved soap" as a potential citation to Howe's patent No. 4,750 because making the soap requires "Anhydrous caustic soda about 4,750 kilograms."

${ }^{23}$ The Smithsonian data confirm that citations may be biased towards more recent inventions (Hall, Jaffe, and Trajtenberg, 2001). Forty-two percent of cited patents in our data were issued after 1880, compared with 9 percent of the Smithsonian patents. No pool patent was cited after 1920 but 6 were selected by the Smithsonian. The average Smithsonian patent received 0.14 citations after 1920, compared with 0.17 for other patents between 1850 and 1880 .
} 
to a specific stitch make it possible to assign another 6 machines. ${ }^{24}$ Of these 146 total firms, 78 sewed the lockstitch, 61 the chain stitch, and 7 another stitch. Thirty-five of 170 entrants were licensees of the sewing machine pool (Depew, 1895; Cooper, 1976); 22 licensees entered with the lockstitch, 10 with the chain stitch, 2 with other stitches, and 1 with an unknown stitch.

\section{Selection bias - underestimate innovation by small producers of substitutes}

Firms that produced substitutes for pool technologies were smaller, more likely to exit and therefore less likely to leave behind a traceable record. In a data set of annual sales for 27 licensees, the average chain stitch licensee produced 5,552 machines per year between 1867 and 1876, compared with 16,890 for lockstitch licensees (Cooper, 1976, p. 40). Some licensees produced as little as 100 machines per year, and fewer than 500 machines while they were in business (Depew, 1895, p. 530). Our data include some small firms, such as the Union Buttonhole Machine Co. and C. F. Thompson, which each produced fewer than 150 machines (Cooper, 1976, p. 40), but probably not all. A comparison with the U.S. census of manufacturing suggests that we may be especially likely to miss small producers of chain stitch machines in the early years of the pool (Lampe and Moser 2010). The census of 1860 counts 74 sewing machine firms; we capture 29 firms with known years of entry and exit in that year. The census of 1870 counts 49 firms; our data capture 31 firms.

\section{RESULTS}

\section{A. Patenting spikes in the early years of the pool and then declines}

\footnotetext{
${ }^{24}$ For example, the New York Shuttle, can be uniquely identified as a lockstitch machine because only lockstitch machines used a shuttle (Urquhat, 1881, p. 26).
} 
Patent data indicate that invention in sewing machine increased immediately after the pool had formed, both in absolute terms and relative to other industries. Before the pool formed, a total of 25 sewing machine patents were granted in 1856 (1.1 percent of all U.S. patents, Figure 1); immediately after the pool formed, 51 patents were granted in 1857, 92 in 1858, 75 in 1859, and 73 in $1860(1.9,2.7,1.8$, and 1.7 percent of all U.S. patents, respectively). After this initial increase patenting declined until the pool dissolved again. In 1867, 68 patents were granted for sewing machines (0.6 percent of all U.S. patents). After the pool dissolved, patenting increased again to 259 patents in 1882 (nearly 1.5 percent of U.S. patents).

A comparison with Britain, which did not have a pool, indicates that this decline in patenting cannot be explained by natural variation in patenting rates over the life cycle of the sewing machine industry; in Britain, sewing machine patenting followed a continuous path for the duration of the pool (Figure 1). ${ }^{25}$ Data on improvements in sewing speeds (as an alternative measure of innovation to control for strategic patenting) confirm that innovation slowed after the pool formed and did not recover until it had dissolved (Lampe and Moser, 2010, p. 917).

\section{B. This spike in patenting is driven by an increase in patenting for the substitute}

Why did patenting increase in the early years of the pool? An analysis at the level of individual technologies reveals a substantial shift towards inventions in the chain stitch even though it was understood to be technologically inferior. ${ }^{26}$ Between 1850 and 1855, 4.0 chain stitch inventions were patented per year, compared with 3.3 lockstitch inventions (Figure 3).

\footnotetext{
${ }^{25}$ Two British patents in 1861 and 1865 refer to "single-thread machines" in the title; these could be chain stitch machines. Twenty-seven patents refer to lockstitch machines; of these patents, 3 while the pool was active, and 24 after it had dissolved.

${ }^{26}$ The alternative explanation that the prospect of a pool provoked a patent race (Dequiedt and Versaevel, 2007), and that patents which resulted from this race were granted with some delay, is not supported by the data. Twelve of 50 chain stitch patent grants in 1858 include application dates; the earliest is October 23, 1857 (U.S. patent 19,015), nearly one year after the pool had formed.
} 
Between 1857 and 1862, 21 chain stitch inventions were patented per year compared with 12.3 lockstitch inventions.

After the pool dissolved, the focus of innovation reverted to the pool technology and away from the substitute: From 1877 to $1885,4.0$ chain stitch inventions were patented per year, compared with 21.3 lockstitch inventions.

OLS and negative binomial regressions test whether this shift toward chain stitch invention may have been driven by alternative factors, including variation at the level of technologies and over time:

$$
\begin{aligned}
\text { patents }_{c t}=\alpha & +\beta_{1} \text { pool }_{t} * \text { chain stitch }_{c}+\beta_{2} \text { pool }_{t} * \text { chain stitch }_{c} * \text { pool age }_{t} \\
& +\beta_{3} \text { pool }_{t} * \text { lockstitch }_{c}+\beta_{4} \text { pool }_{t} * \text { lockstitch }_{c} * \text { pool age }_{t} \\
& +\delta_{t}+f_{c}+\varepsilon_{c t}
\end{aligned}
$$

where the dependent variable measures patents per subclass $c$ and year $t$. The binary variable pool equals one for years from 1857 to 1876 , when the pool was active for the entire year; it equals 0 in 1856 and 1877 , even though the pool was active for part of these years, which will lead us to underestimate the effects of the pool. Binary variables for chain stitch and lockstitch distinguish subclasses of chain stitch inventions (USPTO subclasses 173-175 and 197-202 in the main class sewing) and lockstitch inventions (USPTO subclasses 181-196).

Under the assumption that, in the absence of a pool, changes in patents per year would not have been systematically different for chain stitch and lockstitch technologies, compared with other sewing machine inventions, coefficients for pool * chain stitch and pool * lockstitch measure the effects of the pool on the direction of technical change. Interactions with pool age test whether the pool's effects on innovation weakened as its patents aged. $\delta_{t}$ and $f_{c}$ control for year and subclass fixed effects. To be conservative, standard errors are clustered at the level of 
subclasses instead of pool versus substitute technologies, which would reduce the size of the error.

Estimates imply that chain stitch subclasses produced 2.6 additional patents per year while the pool was active compared with subclasses of other sewing machine inventions (significant at 1 percent, Table 3, column 1), implying a 6-fold increase relative to the mean of 0.42 patents per subclass and year (Table 2). In comparison, lockstitch subclasses produced only 0.35 additional patents while the pool was active (not statistically significant, Table 3 , column 1). ${ }^{27}$ An estimate of 0.19 for pool $^{*}$ chain stitch $*$ pool age implies that the differential increase in chain stitch patenting declined by 0.19 patents per year (significant at 1 percent, Table 3 , column 1), while estimates for pool*lockstitch*pool age are negative and not statistically significant, suggesting that the effects of the pool declined as its patents aged and weakened.

Results are robust to the inclusion of linear and quadratic time trends (with estimates of 2.53 to 2.59 for pool $^{*}$ chain stitch (Table 3, column 2-4). Estimates are also robust to alternative specifications that replace subclass fixed effects with dummy variables to distinguish chain stitch and lockstitch subclasses (Table 3, column 3), and replace year fixed effects with a dummy variable for pool years (Table 3, column 4). ${ }^{28}$ Results are also robust to dropping any subclass from the sample, and to alternative assignments of subclasses that could include either lockstitch or chain stitch inventions. ${ }^{29}$

\footnotetext{
${ }^{27}$ A Wald test statistic of 5.19 (Table 3, column 1) rejects the hypothesis that the coefficients for pool*lockstitch and pool*chain stitch are equal with a p-value of 0.02 .

${ }^{28}$ Results are also robust to controlling directly for the potential demand effects of the American Civil War (18611865). Anecdotal evidence suggests that the war favored the lockstitch. Demand for lock stitch machines increased with the demand for durable, machine-sewn uniforms by the Union Army (Whitten and Whitten, 2000, p. 91-92), whose size increased from 16,267 soldiers in January 1861 to 959,460 in January 1865 (Long and Long, 1971). Singer, for example, sold thousands of lockstitch machines to the Union Army (Botti, 2006, p. 97). Regressions that control for increases in the size of the Union Army yield slightly larger estimates for a shift towards the chain stitch, and indicate that every additional 10,000 soldiers reduced patenting overall by 0.003 (significant at the 1 percent level).

${ }^{29}$ Subclass 199 (Oscillating or reciprocating looper) produced 49 patents between 1857 and 1860, compared with 17 patents between 1849 and 1856, and 34 patents between 1861 and 1877. Excluding it reduces the estimate for
} 
Additional robustness checks repeat the main specifications as negative binomial regressions to control for the count data characteristics of the outcome variable, and restrict the sample to primary subclasses and subclasses that existed in 1856 to control for the specific characteristics of the U.S. patent system. Negative binomial regressions indicate a slightly larger shift towards chain stitch innovation: Chain stitch subclasses produced 640 percent more patents while the pool was active (exp (1.996)-1=6.4; significant at 1 percent, Table 4, column 1), while lockstitch subclasses produced 70 percent more patents. ${ }^{30}$ As the pool aged, the effect on chain stitch patents declined by 11 percent per year (significant at 1 percent, Table 4 , column 1 ).

Restricting the sample to primary subclasses also leaves the estimates substantially unchanged. Each U.S. patent is assigned to one primary and potentially one or more secondary, or cross-reference, subclasses. To capture the full effects of the pool we include both types of subclasses in the main specifications, and drop cross-reference subclasses in this robustness check to ensure that the results are not driven by their inclusion in the main regressions. ${ }^{31}$ Regressions with the restricted sample indicate that chain stitch subclasses produced 2.4 additional patents while the pool was active, implying an 800 percent increase compared with an average of 0.3 patents per subclass and year, while lockstitch subclasses produces 0.4 additional

\footnotetext{
pool*chain stitch to 1.7 with a standard error of 0.6 . Excluding other chain stitch subclasses leaves the estimates above 2.3. Three subclasses for machines that use multiple needles could be either chain stitch or lockstitch inventions (112:164-166). Between 1845 and 1885, these subclasses produced a total of 11 patents. Regressions that include these subclassses yield a coefficient of 2.2 for pool $^{*}$ chain stitch with a standard error of 0.82 . Another subclass (112:168) includes machines that can switch between stitch types; it produced 53 patents. Knight (1876) includes information on the stitch type for 32 patents in this subclass; 30 of them are lockstitch machines. Results are robust to including this subclass as a lockstitch subclass (with coefficients of 2.6 for pool*chain stitch and 0.4 for pool $*$ lockstitch with standard errors of 1.0 and 0.1 , respectively).

${ }^{30}$ A Wald test statistic of 16.75 (Table 4, column 1 ) rejects the hypothesis that the coefficients for pool*chain stitch and pool*lockstitch are equal with a p-value of 0.00 . We use Wald tests instead of likelihood ratios because the likelihood ratio statistic may not be distributed as a chi-square with standard errors that are clustered at the level of subclasses, i.e. not homoscedastic (Cameron and Trivedi, 2009).

${ }^{31} 1,080$ of 4,576 sewing machine patents between 1845 and 1885 are assigned to one or more secondary subclass; the median patent is assigned to 1 subclass, the average is assigned to 1.36 , and 1 is assigned to 9 secondary subclasses. Forty-two of 362 subclasses are never listed as a primary subclass; 1 of them (174 - "Running Stitch: Crimping") covers the chain stitch; none cover lockstitch inventions.
} 
patents, implying a 133 percent increase (significant at 1 percent, Table 4, column 3). As the pool's patents aged, its effect declined by roughly 0.2 patents per year after 1857 (significant at 1 percent, Table 4, column 3), implying a 6.9 percent decline per year.

A final robustness check drops all 266 subclasses that produced no patents before 1856; these subclasses include new technologies that did not exist when the pool formed. Two of them cover the chain stitch, 5 the lockstitch, and 259 are for other improvements in sewing machines. In regressions with the restricted sample of subclasses that existed at the creation of the pool, chain stitch subclasses produced 3.0 additional patents after the pool had formed (significant at 5 percent, Table 4, column 5) compared with 0.8 patents per subclass and year in this sample. In comparison, lockstitch subclasses produced only 0.4 additional patents after the pool had formed (Table 4, column 5). ${ }^{32}$

\section{Annual effects with controls for pre-existing time trends}

An alternative test estimates variation in patenting for pool technologies and substitutes separately for each year by estimating annual effects controlling for pre-existing trends. Specifically, we allow the coefficients for pool $*$ chain stitch and pool $*$ lockstitch to be different from zero for eight years before the pool (1849-1857) to control for unobservable factors that preceded the creation of the pool, but may have created a differential increase in chain stitch patenting after the pool had formed. ${ }^{33}$

$$
\begin{aligned}
\text { patents }_{c t}=\alpha & +\beta_{1 t} I(1849-1876)_{t} * \text { chain stitch }_{c}+\beta_{2 t}{\text { I(1849-1876 })_{t} * \text { lockstitch }_{c}} \\
& +\delta_{t}+f_{c}+\varepsilon_{c t}
\end{aligned}
$$

\footnotetext{
${ }^{32}$ A Wald test statistic of 4.24 rejects the hypothesis that estimates for pool*chain stitch and pool*lockstitch are equal with a $p$-value of 0.04 .

${ }^{33} 1849$ is the first year with a significant number of sewing machine patents. A total of seven patents were granted between 1845 and 1848 .
} 
where the indicator variable $I(1849-1876)_{t}$ is equal to 1 for any year between 1849 and 1876 ; as above, $\delta_{t}$ estimates annual fixed effects and $f_{c}$ subclass fixed effects.

For 1858 - two years after the creation of the pool - year-specific coefficients indicate that subclasses with chain stitch patents produced 6.4 additional patents (significant at 5 percent, Figure 4), implying a 16-fold increase compared with a mean of 0.4 patents per subclass and year. Year-specific coefficient estimates remain positive and significant until $1865 .^{34}$ All estimates allow for variation in patenting across pool technologies and substitutes before the creation of the pool. Coefficients for the pre-period are statistically significant but comparatively small (between 0.4 and 1.0).

\section{Controlling for the quality of patents}

Data for high-quality inventions indicate a significant, but substantially smaller shift towards chain stitch invention after the creation of the pool, suggesting that the shift towards chain stitch inventions created fewer high quality patents. Between 1857 and 1861, 14 of 42 cited patents were for the chain stitch, compared with 5 of 21 cited patents between 1845 and 1856. Difference-in-differences regressions indicate that chain stitch subclasses generated 0.26 additional cited patents per year while the pool was active (significant at 10 percent, Table 3 , column 5), implying a 371 percent increase, compared with an average of 0.07 cited patents per subclass and year. As its patents aged, the pool's effect on chain stitch invention weakened by 0.02 patents per year (significant at 5 percent, Table 3, column 5). At the same time, the pool had a negative, albeit not statistically significant effect on lockstitch patents.

\footnotetext{
${ }^{34}$ In regressions that do not control for the pre-trend, the estimated effect of the pool on chain stitch patenting is slightly smaller in the early years and persists until 1862. Results are robust to including quadratic time trends for lockstitch and chain stitch subclasses; annual effects range between 1.1 and 5.7 between 1857 and 1861 (significant at 10 percent, not reported).
} 
Regressions for Smithsonian patents - as an alternative measure of quality - yield similar results. Between 1850 and 1856, 12 of 48 Smithsonian patents were for the chain stitch; between 1857 and 1862, 88 of 179 Smithsonian patents - roughly half - were for the chain stitch (Figure 5). Difference-in-difference estimates indicate that chain stitch subclasses produced 1.83 additional Smithsonian patents per year (significant at 1 percent, Table 3, column 6), compared with an average of 0.07 Smithsonian patents per subclass and year. Interactions with pool age imply that the pool's effect on chain invention weakened by 0.12 Smithsonian patents per year (significant at 1 percent, Table 3, column 6). In comparison, the effect on lockstitch patents is substantially smaller at 0.2 additional patents per year. ${ }^{35}$

\section{Technologies of New FiRMS AS An Alternative MeAsure of InNOVATiON}

Although patent data suggest that the creation of a pool encouraged innovation in substitutes, the observed shift may be due to changes in the need for strategic patenting rather than reflect a true change in innovation. Most importantly, if the pool reduced litigation risks for outsiders that produced the pool technology, it may have reduced the need for strategic patenting in the pool technology relative to the substitute. ${ }^{36}$ To explore this effect, we examine changes in the technology choice of new firms as an alternative measure of innovation.

Entry data confirm that innovation shifted towards substitutes for pool technologies after the pool had formed. Between 1850 and 1856, only 7 of 27 new firms entered with a chain stitch machine. In 1857, all 9 new firms entered with chain stitch machines. This emphasis on the

\footnotetext{
${ }^{35}$ A Wald test statistic of 5.99 (Table 3, column 6) rejects the hypothesis that the coefficients on pool*chain stitch and pool*lockstitch stitch are equal with a p-value of 0.01 .

${ }^{36}$ Survey data indicate that firms use patents to protect themselves from litigation (Cohen, Nelson, and Walsh, 2000; Hall and Ziedonis, 2001). In the biotech sector, firms are less likely to patent in crowded subclasses where the risk of litigation might be higher (Lerner, 1995). In 19th-century data, the share of innovations that are patented varies strongly across industries and increases in response to scientific breakthroughs that increase the risk of reverse engineering (Moser, 2005, 2012). In contemporary data for the United States, there is also evidence of strategic behavior in patent citations (Lampe, 2010).
} 
chain stitch persisted after Howe's lockstitch patent expired in 1867 . In that year, 5 of 10 entrants produced chain stitch machines (Figure 6). ${ }^{37}$ The share of chain stitch entries only began to fall in 1871, when the pool's last remaining patents were about to expire. After the pool dissolved in 1877 , only 1 of 26 firms entered with a chain stitch machine. ${ }^{38}$

\section{Why may Patent PoOls Encourage InNOvation in Substitutes?}

Data on patent grants and the technologies of new firms in the sewing machine industry indicate that the creation of a pool encouraged innovation in substitutes. This finding is surprising because it contradicts an intuitive concern about pools that combine complementary patents. Pools of complementary patents may discourage innovation in substitute technologies even if they are technologically superior because they create a competitive advantage for pool technologies, which benefit from complementarities with other pool patents. Evidence that patent pools encourage innovation in substitutes, however, is exceedingly robust.

\section{A. Vertical differentiation and differential license fees}

How might the creation of a pool encourage innovation in substitute technologies? The case of the sewing machine industry suggests that the creation of a pool may encourage innovation in substitutes by increasing incentives for outside firms to vertically differentiate their

\footnotetext{
${ }^{37}$ The tenth entrant, the American Buttonhole, Overseaming and Sewing Machine Company produced a machine for buttonhole sewing, which we assign to "other stitch." Patent data also suggest that firms specialized in either the lock or the chain stitch. For example, Wheeler \& Wilson and the Howe Machine Company only patented lockstitch technologies between 1849 and 1885, while Willcox \& Gibbs only patented chain stitch machines during this period. Singer (a lockstitch manufacturer) patented only two inventions related to the chain stitch (USPTO 10,842 and 10,974 in 1854), while Grover \& Baker (a chain stitch manufacturer) patented only one invention related to the lockstitch (U.S. patent 118,450 in 1871).

${ }^{38}$ Regional differences in the choice of technologies cannot explain these changes. Approximately equal shares of new firms entered with chain stitch machines in the early years across the Midwest and the Northeast: between 1857 and 1876, 4 of 9 (44 percent) entrants in the Midwest manufactured chain stitch machines, compared with 25 of 57 (44 percent) entrants in the Northeast. Between 1867 and 1876, fewer entrants produced chain stitch machines in both regions; 1 of 5 (20 percent) in the Midwest compared with 10 of 24 (42 percent) in the Northeast.
} 
products from the pool technology. If the pool combines complementary patents that allow its members to produce a high-quality product, and sell it at a high price, it creates a market niche for outsiders to offer lower quality substitutes at a lower price. ${ }^{39}$ This market niche is particularly attractive relative to improving the pool technology, if the creation of a pool increases litigation risks for outside firms.

Price data are consistent with this idea. While the pool was active, the average chain stitch sewing machine sold for $\$ 39$, while the average lockstitch machine sold for $\$ 71 .^{40}$ The example of Willcox \& Gibbs - one of the pool's most powerful competitors, - lends additional support to idea of vertical differentiation. Considering Singer and other pool machines "entirely too heavy, complicated, and cumbersome, and the price exorbitant" (Cooper, 1976, p. 45), Willcox entered in 1857 with the twisted-loop stitch, a lower-priced substitute. ${ }^{41}$ At $\$ 50$ (Cooper, 1976, p. 36), Wilcox \& Gibbs's machine was priced between the lower-quality chain stitch (\$33 in the late 1850s) and pool models (e.g., \$100 for Wheeler \& Wilson's with the same accessories, Cooper, 1976, p. 47). In response, Singer reduced the price for to its entry-level (light) family machine, which it had introduced in 1858 , to $\$ 50$ almost immediately. In 1859 , Singer offered an improved family machine for \$75 (Cooper, 1976, p. 47). Between 1867 and 1876, Willcox \& Gibbs sold 19,588 machines per year, compared with 104,317 machines for the

\footnotetext{
${ }^{39}$ The pool technology may be sold at a higher price because the pool created a certain degree of market power or because producing pool's technology, which was "more complicate" required "higher costs of manufacturing" (Cooper, 1976, p. 48). In 1877, for example, leading producers of $\$ 60$ and $\$ 70$ machines incurred average production costs of $\$ 11$ to $\$ 15$ per machine (New York Times, May 8, 1877).

${ }^{40}$ As late as 1877 , licensees sold lockstitch machines for $\$ 60$ to $\$ 70$. Price data from Cooper (1976), Bays (2007), and trade cards from the Historical Trade Literature in the Smithsonian Collection.

${ }^{41}$ Willcox \& Gibbs' stitch is typically treated as a chain stitch because of its single thread, although it differed "as much as so as any two stitches made" (Flint, 1873, p. 425).
} 
average pool member (Cooper, 1976, p. 40, Figure 2). In 1877, after the pool had ended, Singer began to sell its family machine for $\$ 30$ (New York Times, May 8,1877$){ }^{42}$

Differential fees for outside firms and pool members may have further reduced expected profits from improving pool technologies. After the pool formed, license fees fell to $\$ 5$ for member firms, but remained comparatively high at $\$ 15$ for outside firms. Given this difference in fees, a disproportionate number of new firms entered with the chain stitch technology, compared with the lockstitch (25 and 9 entrants, respectively, Table 5).

As the gap between member and non-member fees narrowed, more firms chose to patent and enter with the pool technology. With license fees at $\$ 7$ for outside firms (and \$1 for members) between 1861 and 1867, outside firms patented a total of 42 chain stitch inventions, compared with 60 lockstitch invention between 1861 and 1867. Thirteen firms entered with chain stitch machines, compared with 8 firms that entered with lockstitch machines. With license fees at $\$ 3$ between 1871 and 1876, outside firms patented 22 improvements in the chain stitch, compared with 100 improvements in the lockstitch; during this time, 5 firms entered with chain stitch and 12 with lockstitch machines. After the pool dissolved in 1877 , outside firms patented 35 chain stitch inventions, compared with 192 lockstitch inventions between 1877 and 1885; 25 firms entered with lockstitch machines and 2 with chain stitch machines (Table 5).

Although the number of licensees (and their patents) is relatively small, data on patenting and entry are suggestive. Firms that chose to license the pool technology were more likely to use the lockstitch than the chain stitch across all years, but we observe a significant increase in lockstitch patenting only towards the end of the pool.

\footnotetext{
${ }^{42}$ Unlike other competitors, Willcox \& Gibbs survived competition with the pool, and remained in business selling machines for industrial use until 1973 (Bays, 2007, p. 263). Most modern-day chain stitch (single-thread) machines sew a stitch that is based on Willcox \& Gibbs'.
} 


\section{CONCLUSIONS}

While regulators expect patent pools of complementary patents to encourage innovation in pool technologies at the expense of substitutes, data for the sewing machine industry indicate the opposite effect. Pool members and other firms produced fewer patents after the pool had formed and more patents after it had dissolved. Moreover, improvements in technical performance slowed after the pool had formed and increased again after it had dissolved. A temporary spike in patenting in the early years of the pool was due to a shift towards patenting in technologically inferior substitutes that did not compete directly with the pool technology. In the early years after the pool had formed, outside firms produced six times as many patents for substitutes relative to the pre-pool period. Results are robust to a broad range of alternative specifications, including separate time trends for pool technologies and substitutes, controls for the quality of patents, and negative binomial regressions to control for the count data nature of patents. Moreover, data on the technology choice of new firms, as an alternative measure of innovation, confirm that innovation shifted towards substitute technologies after the pool had formed, and shifted back to pool technologies after it had dissolved.

Why may patent pools encourage innovation in substitutes at the expense of pool technologies? Most importantly, the creation of a patent pool strengthens incentives for outside firms to differentiate their products vertically from the pool technology. Specifically, the creation of a pool that combines complementary components of the state-of-the-art technology allows member firms to market a high-quality product at a relatively high price, which creates a market niche for outside firms to enter with a lower quality, cheaper substitute. Price data confirm that substitute technologies -which were well understood to be technologically inferior were significantly cheaper than the pool technology. 
This shift in R\&D towards inferior substitutes is further encouraged by two complementary mechanisms, which make it hard for outsiders to compete directly with a pool. First, the introduction of differential license fees raises production costs for outsiders relative to pool members, and reduces average profits for outsiders that improve the pool technology. Second, pools that increase litigation risks for outside firms reduce expected profits especially for outsiders whose products are closer to the pool's technology.

How can these findings be generalized to contemporary pools? A key benefit of the historical setting is that the sewing machine pool operated in the complete absence of regulation, effectively recreating the standard assumptions of theoretical models. Contemporary pools, however, are subject to antitrust regulation under the Sherman Act to mitigate mechanisms, such as differential license fees and differential litigation risks that impact the ability of outsiders to compete with the pool. The experience of the sewing machine industry suggests that additional empirical analyses are needed to better understand if and under what conditions pools can help to encourage innovation.

\section{REFERENCES}

BAYS, C. 2007. The Encyclopedia of Early American and Antique Sewing Machines: Identification and Values. Paducah, KY: Collector Books.

BERRY, S., AND J. WALDFOGEL. 2010. "Product Quality and Market Size.” Journal of Industrial Economics, Vol. 58, pp. 1-31.

BISSELl, D. 1999. The First Conglomerate: 145 Years of the Singer Sewing Machine Company. Brunswick, ME: Audenreed Press.

BotTI, T. 2006. Envy of the World: A History of the U.S. Economy \& Big Business. New York, NY: Algora Publishing.

Brown, T. 1994. Historical First Patents: The First United States Patent for Many Everyday Things. Metuchen, NJ: Scarecrow Press. 
Cameron, A.C., ANd Trivedi, P.K. 2009. Microeconometrics Using Stata. College Station, TX: Stata Press.

CoOPER, G.R. 1976. The Sewing Machine: Its Invention and Development. Washington DC: The Smithsonian Press.

Department of Justice and Federal Trade Commission. 1995. "Antitrust Guidelines for the Licensing of Intellectual Property." Washington, DC: GPO. Available at http://www.justice.gov/atr/public/guidelines/0558.htm.

Department of Justice And Federal Trade Commission. 2007. “Antitrust Enforcement and Intellectual Property Rights: Promoting Innovation and Competition." Washington, DC: GPO. Available at http:// www.usdoj.gov/atr/public/hearings/ip/222655.pdf.

DePartment OF JUSTICE. 1999. "Business Review Letter for DVD Standards Pool, June 10, 1999.” Available at http://www.usdoj.gov/atr/public/busreview/2485.htm.

DEPEw, C.M. 1895. One Hundred Years of American Commerce. New York, NY: D.O. Haynes and Co..

Dequiedt, V., AND Versaevel, B. 2007. "Patent Pools and the Dynamic Incentives to R\&D." Working Paper No. 703, Groupe d'Analyse et de Théorie Économique, Université de Lyon.

Flint, C.L., MCCay, C.F., Merriam, J.C., Kettell, T.P., BrocketT, L.P., AND Hodge, J.T. 1873. One hundred years' progress of the United States: with an appendix entitled Marvels that our grandchildren will see; or, One hundred years' progress in the future. Hartford, CT: L. Stebbins.

GABSzEWICZ, J., AND THISSE, J.F. 1979. "Price competition, quality and income disparities." Journal of Economic Theory, Vol. 20, pp. 340-59.

GALLINI, N. 1992. "Patent Length and Breadth with Costly Imitation." RAND Journal of Economics, Vol. 44, pp. 52-63.

GilberT, R. 2004. “Antitrust for Patent Pools: A Century of Policy Evaluation.” Stanford Technology Law Journal.

Hall, B., JAfFe, A., And Trajtenberg, M. 2001. "The NBER Patent Citation Data File: Lessons, Insights and Methodological Tools.” NBER Working Paper No. 8498.

Hounshell, D. 1984. From the American System to Mass Production, 1800-1932. Baltimore, MD: John Hopkins University Press.

JACK, A. 1856. "The Channels of Distribution for an Innovation: The Sewing Machine Industry in America, 1860-1865." Explorations in Entrepreneurial History, Vol. 9, pp. 113-41. 
KNIGHT, E. 1877. Knight's American Mechanical Dictionary. New York, NY: Hurd and Houghton.

LAMPE, R. "Strategic Citation.” Review of Economics and Statistics, forthcoming.

LAMPE, R., AND Moser, P. 2010. "Do Patent Pools Encourage Innovation? Evidence from the $19^{\text {th }}$-Century Sewing Machine Industry." Journal of Economic History, Vol. 70, pp. 898-920.

LAYNe-FARrAR, A., AND Lerner, J. 2011. “To Join or Not to Join: Examining Patent Pool Participation and Rent Sharing Rules." International Journal of Industrial Organization, Vol. 29, pp. 294-303.

Lerner, J., Strojwas, M., And Tirole, J. 2007. "The Design of Patent Pools: The Determinants of Licensing Rules." RAND Journal of Economics, Vol. 38, pp. 610-25.

Lerner, J., AND Tirole, J. 2004. "Efficient Patent Pools.” American Economic Review, Vol. 94, pp. 691-711.

Long, E.B., AND Long, B. 1971. The Civil War day by day; an almanac, 1861-1865. Garden City, NY: Double Day \& Company.

MergeS, R. 2001. "Institutions for Intellectual Property Transactions: The Case of Patent Pools.", In Expanding the Boundaries of Intellectual Property: Innovation Policy for the Knowledge Society, edited by R. Dreyfuss. Oxford: Oxford University Press.

Moser, P. 2005. "How Do Patent Laws Influence Innovation? Evidence from NineteenthCentury World Fairs" American Economic Review, Vol. 95, pp. 1215-236.

Moser, P. 2012. "Innovation without Patents - Evidence from the World Fairs" Journal of Law and Economics, forthcoming.

Moser, P., Ohmstedt, J., ANd Rhode, P. 2011. "Patents and the Size of the Inventive Step." Working Paper, Stanford University.

Parton, J. 1867. "History of the Sewing Machine.” Atlantic Monthly, May.

QuINT, D. 2009. "Pooling With Essential and Nonessential Patents." Working Paper, University of Wisconsin.

Shaked, A., And SutTon, J. 1982. "Relaxing Price Competition Through Product Differentiation." Review of Economic Studies, Vol. 49, pp. 3-13.

SHAPIRo, C. 2001. "Navigating the Patent Thicket: Cross Licenses, Patent Pools, and Standard Setting." In Innovation Policy and the Economy, edited by Jaffe, A., Lerner, J., and Stern, S. Cambridge, MA: MIT Press.

TIROLE, J. 1988. The Theory of Industrial Organization. Cambridge, MA: MIT Press. 
Thomson, R. 1987. "Learning by Selling and Invention: The Case of the Sewing Machine." Journal of Economic History, Vol. 47, pp. 433-45.

Trajtenberg, M. 1990. “A Penny for Your Quotes: Patent Citations and the Value of Innovations." RAND Journal of Economics, Vol. 21, pp. 172-87.

URQUHART, J. 1881. Sewing Machinery. London: Crosby Lockwood \& Company.

United States Patent Office. 2000. "Patent Pools: A Solution to the Problem of Access to Biotechnology Patents?” Washington, DC: GPO. Available at www.uspto.gov/web/offices/pac/dapp/opla/patentpool.pdf.

Vaughan, F. 1956. The United States Patent System: Legal and Economic Conflicts in American Patent History. Norman, OK: University of Oklahoma Press.

WhitTen, D.O., AND Whitten, B.E. 2000. Handbook of American Business History. New York: Greenwood Publishing Group.

Williamson, S. 2010. "Six Ways to Compute the Relative Value of a U.S. Dollar Amount, 1774 to Present," MeasuringWorth. 
Table 1: Number of Patents, Cited Patents and Patents SElected By the Smithsonian 1845-1885

\begin{tabular}{|c|c|c|c|c|c|c|c|c|c|}
\hline \multirow[b]{2}{*}{ Technology Type } & \multicolumn{3}{|c|}{ Total Patents } & \multicolumn{3}{|c|}{ Cited Patents } & \multicolumn{3}{|c|}{ Smithsonian Patents } \\
\hline & $\begin{array}{c}\text { Chain stitch } \\
\text { (1) }\end{array}$ & $\begin{array}{l}\text { Lockstitch } \\
\text { (2) }\end{array}$ & $\begin{array}{l}\text { Other } \\
\text { (3) }\end{array}$ & $\begin{array}{c}\text { Chain stitch } \\
\text { (4) }\end{array}$ & $\begin{array}{c}\text { Lockstitch } \\
\text { (5) }\end{array}$ & $\begin{array}{l}\text { Other } \\
(6)\end{array}$ & $\begin{array}{c}\text { Chain stitch } \\
\text { (7) }\end{array}$ & $\begin{array}{c}\text { Lockstitch } \\
\text { (8) }\end{array}$ & $\begin{array}{l}\text { Other } \\
(9)\end{array}$ \\
\hline Pre-Pool (1845-56) & 30 & 30 & 94 & 5 & 6 & 10 & 12 & 15 & 23 \\
\hline Pool (1857-76) & 192 & 280 & 1,917 & 17 & 19 & 208 & 124 & 98 & 280 \\
\hline Post-Pool (1877-85) & 35 & 192 & 1,809 & 9 & 23 & 321 & 9 & 21 & 129 \\
\hline All Years & 257 & 502 & 3,820 & 31 & 48 & 539 & 145 & 134 & 432 \\
\hline
\end{tabular}

Notes: Cited patents - as a measure of quality - count all sewing machine patents between 1845 and 1885 that are cited by at least one other patent between 1920 and 1974. Smithsonian patents - as an alternative measure of patent quality - count patents that were selected by curators of the Smithsonian as significant inventions. Chain stitch patents cover the substitute for the pool technology; these are patents are in USPTO subclasses 112:173-175 and 112:197-202. Lockstitch patents cover the pool technology; these are patents in subclasses 112:181-196.

Table 2: Mean of Patents Per Subclass and Year Across Pool Technologies and Substitutes

\begin{tabular}{lccc}
\hline \hline & $\begin{array}{c}\text { Chain Stitch Subclasses } \\
\text { (Substitute for the Pool } \\
\text { Technology) }\end{array}$ & $\begin{array}{c}\text { Lockstitch Subclasses } \\
\text { (Pool Technology) }\end{array}$ & $\begin{array}{c}\text { Other Subclasses in } \\
\text { "Sewing” }\end{array}$ \\
\hline Pre-Pool (1845-56) & 0.31 & 0.16 & 0.04 \\
Pool (1857-76) & 1.21 & 0.88 & 0.40 \\
Post-Pool (1877-85) & 0.50 & 1.33 & 0.85 \\
\hline All Years & 0.79 & 0.77 & 0.44 \\
\hline \hline
\end{tabular}

Notes: Data include all 4,576 patents granted between 1845 and 1885 in USPTO class 112 Sewing. Chain stitch patents cover the substitute for the pool technology; these are patents are in USPTO subclasses 112:173-175 and 112:197-202. Lockstitch patents cover the pool technology; these are patents are in subclasses 112:181-196. 
TABle 3: OLS - DePendent VARIAble is Patents Per Subclass ANd Year

\begin{tabular}{|c|c|c|c|c|c|c|}
\hline & \multicolumn{4}{|c|}{ All Patents } & \multicolumn{2}{|c|}{$\begin{array}{l}\text { Controlling for patent quality } \\
\text { (5)-(6) }\end{array}$} \\
\hline & $(1)$ & $(2)$ & (3) & $(4)$ & $\begin{array}{c}\text { Cited Patents } \\
(5)\end{array}$ & $\begin{array}{c}\text { Smithsonian } \\
(6)\end{array}$ \\
\hline Pool*Chain stitch & $\begin{array}{l}2.632 * * \\
(0.947)\end{array}$ & $\begin{array}{l}2.525^{*} \\
(0.981)\end{array}$ & $\begin{array}{l}2.525^{* *} \\
(0.969)\end{array}$ & $\begin{array}{l}2.594 * * \\
(0.967)\end{array}$ & $\begin{array}{c}0.263 \\
(0.159)\end{array}$ & $\begin{array}{l}1.828 * * \\
(0.663)\end{array}$ \\
\hline Pool*Chain stitch*Pool Age & $\begin{array}{c}-0.193 * * \\
(0.066)\end{array}$ & $\begin{array}{c}-0.175^{* *} \\
(0.064)\end{array}$ & $\begin{array}{c}-0.175^{* *} \\
(0.064)\end{array}$ & $\begin{array}{c}-0.168 * * \\
(0.064)\end{array}$ & $\begin{array}{r}-0.023^{*} \\
(0.010)\end{array}$ & $\begin{array}{c}-0.116 * * \\
(0.040)\end{array}$ \\
\hline Pool*Lockstitch & $\begin{array}{c}0.353 \\
(0.328)\end{array}$ & $\begin{array}{l}0.326^{*} \\
(0.146)\end{array}$ & $\begin{array}{l}0.326^{*} \\
(0.145)\end{array}$ & $\begin{array}{c}0.394 * * \\
(0.144)\end{array}$ & $\begin{array}{l}-0.073 \\
(0.038)\end{array}$ & $\begin{array}{l}0.195^{*} \\
(0.078)\end{array}$ \\
\hline Pool*Lockstitch*Pool Age & $\begin{array}{l}-0.016 \\
(0.014)\end{array}$ & $\begin{array}{l}-0.027^{*} \\
(0.011)\end{array}$ & $\begin{array}{l}-0.027^{*} \\
(0.011)\end{array}$ & $\begin{array}{l}-0.021 \\
(0.011)\end{array}$ & $\begin{array}{c}0.002 \\
(0.002)\end{array}$ & $\begin{array}{l}-0.009 \\
(0.005)\end{array}$ \\
\hline Chain stitch & & & $\begin{array}{l}0.366^{*} \\
(0.178)\end{array}$ & $\begin{array}{c}0.037 \\
(0.179)\end{array}$ & & \\
\hline Lockstitch & & & $\begin{array}{l}-0.024 \\
(0.056)\end{array}$ & $\begin{array}{c}-0.353^{* *} \\
(0.061)\end{array}$ & & \\
\hline Pool (=1 between $1857-76)$ & & & & $\begin{array}{c}0.016 \\
(0.026)\end{array}$ & & \\
\hline Constant & $\begin{array}{c}0.576^{* *} \\
(0.043)\end{array}$ & $\begin{array}{c}0.110^{* *} \\
(0.037)\end{array}$ & $\begin{array}{c}0.565^{* *} \\
(0.059)\end{array}$ & $\begin{array}{c}0.385 * * \\
(0.029)\end{array}$ & $\begin{array}{c}0.030 * * \\
(0.010)\end{array}$ & $\begin{array}{l}0.037 * \\
(0.014)\end{array}$ \\
\hline Subclass Fixed Effects & $\mathrm{Y}$ & $\mathrm{Y}$ & $\mathrm{N}$ & $\mathrm{N}$ & $\mathrm{Y}$ & $\mathrm{Y}$ \\
\hline Year Fixed Effects & Y & Y & $\mathrm{Y}$ & $\mathrm{N}$ & $\mathrm{Y}$ & Y \\
\hline Linear and Quadratic Time Trends & $\mathrm{N}$ & Y & Y & Y & $\mathrm{Y}$ & $\mathrm{Y}$ \\
\hline Wald Test Statistic (p-value): & $5.19 *$ & $4.93 *$ & $5.05^{*}$ & $5.07 *$ & $4.23 *$ & $5.99 *$ \\
\hline Pool $*$ Chain stitch $=$ Pool $*$ Lockstitch & $(0.02)$ & $(0.03)$ & $(0.03)$ & $(0.03)$ & $(0.04)$ & $(0.01)$ \\
\hline No. of Observations & 14,842 & 14,842 & 14,842 & 14,842 & 14,842 & 14,842 \\
\hline $\mathrm{R}^{2}$ & 0.32 & 0.32 & 0.11 & 0.02 & 0.15 & 0.22 \\
\hline
\end{tabular}

Notes: The variable pool equals 1 for years between 1857 and 1876; chain stitch counts patents for the substitute technology (subclasses $112: 173$ to 175 and 112:197 to 202); lockstitch counts patents for the pool technology (subclasses 112:181 to 196); other sewing machine patents are the omitted control group. Pool Age counts years after 1857. Cited patents were constructed by searching www.google.com/patents for references in patent grants from 1920 to 1974 to patent numbers between 1845 and 1885; citations for 1975 to 2002 are from Hall, Jaffe and Trajtenberg (2001). Smithsonian patents from Cooper (1976). Wald test for equality of the coefficients on pool*chain stitch and pool*lockstitch. Standard errors are clustered at the subclass level. ** significant at 1 percent, $*$ significant at 5 percent. 
TAble 4: Robustness Checks OlS And Negative Binomial - DePendent Variable is Patents Per Subclass And Year

\begin{tabular}{|c|c|c|c|c|c|c|}
\hline & \multicolumn{2}{|c|}{ "Negative Binomial (1)-(2) } & \multicolumn{2}{|c|}{ Primary Subclasses (3)-(4) } & \multicolumn{2}{|c|}{ "Subclasses active in $1856(5)-(6)$} \\
\hline & $(1)$ & $(2)$ & $(3)$ & (4) & $(5)$ & $(6)$ \\
\hline \multirow[t]{2}{*}{ Pool*Chain stitch } & $1.996^{* *}$ & $1.856^{* *}$ & $2.394 * *$ & $2.394 * *$ & $2.980^{*}$ & $2.980 *$ \\
\hline & $(0.304)$ & $(0.326)$ & $(0.921)$ & $(0.910)$ & $(1.224)$ & $(1.210)$ \\
\hline \multirow[t]{2}{*}{ Pool*Chain stitch*Pool Age } & $-0.120 * *$ & $-0.120 * *$ & $-0.166^{* *}$ & $-0.166^{* *}$ & $-0.208 * *$ & $-0.208 * *$ \\
\hline & $(0.027)$ & $(0.025)$ & $(0.060)$ & $(0.059)$ & $(0.079)$ & $(0.078)$ \\
\hline \multirow[t]{2}{*}{ Pool*Lockstitch } & 0.539 & 0.507 & $0.380 *$ & $0.380 *$ & $0.432 *$ & $0.432 *$ \\
\hline & $(0.283)$ & $(0.264)$ & $(0.149)$ & $(0.147)$ & $(0.213)$ & $(0.211)$ \\
\hline \multirow[t]{2}{*}{ Pool*Lockstitch*Pool Age } & $-0.030 *$ & $-0.033^{*}$ & $-0.028^{*}$ & $-0.028^{*}$ & $-0.040^{*}$ & $-0.040^{*}$ \\
\hline & $(0.014)$ & $(0.013)$ & $(0.011)$ & $(0.011)$ & $(0.016)$ & $(0.016)$ \\
\hline \multirow[t]{2}{*}{ Chain stitch } & & $4.135 * *$ & & $0.335^{*}$ & & 0.411 \\
\hline & & $(0.655)$ & & $(0.170)$ & & $(0.233)$ \\
\hline \multirow[t]{2}{*}{ Lockstitch } & & $2.624 * *$ & & -0.006 & & -0.069 \\
\hline & & $(0.515)$ & & $(0.055)$ & & $(0.088)$ \\
\hline \multirow[t]{2}{*}{ Constant } & $-4.054 * *$ & $-2.289 * *$ & $0.074 *$ & $0.402 * *$ & $0.970 * *$ & $0.325 * *$ \\
\hline & $(0.183)$ & $(0.198)$ & $(0.033)$ & $(0.051)$ & $(0.118)$ & $(0.101)$ \\
\hline Subclass Fixed Effects & $\mathrm{Y}$ & $\mathrm{N}$ & $\mathrm{Y}$ & $\mathrm{N}$ & $\mathrm{Y}$ & $\mathrm{N}$ \\
\hline Year Fixed Effects & $\mathrm{Y}$ & $\mathrm{Y}$ & $\mathrm{Y}$ & $\mathrm{Y}$ & Y & $\mathrm{Y}$ \\
\hline Linear and Quadratic Time Trends & $\mathrm{Y}$ & $\mathrm{Y}$ & $\mathrm{Y}$ & $\mathrm{Y}$ & $\mathrm{Y}$ & $\mathrm{Y}$ \\
\hline Wald Test Statistic (p-value): & $16.75^{* *}$ & $14.04 * *$ & $4.67 *$ & $4.78 *$ & $4.24 *$ & $4.34 *$ \\
\hline Pool $*$ Chain stitch $=$ Pool $*$ Lockstitch & $(0.00)$ & $(0.00)$ & $(0.03)$ & $(0.03)$ & $(0.04)$ & $(0.04)$ \\
\hline No. of Observations & 14,842 & 14,842 & 14,842 & 14,842 & 3,936 & 3,936 \\
\hline No. of Subclasses & 362 & 362 & 362 & 362 & 96 & 96 \\
\hline Log-likelihood / $\mathrm{R}^{2}$ & -8372.24 & -10469.34 & 0.30 & 0.09 & 0.33 & 0.15 \\
\hline
\end{tabular}

Notes: The variable chain stitch counts patents for the substitute technology (subclasses 112:173 to 175 and 112:197 to 202); the variable lockstitch counts patents for the pool technology (subclasses 112:181 to 196); other sewing machine patents are the omitted control group. Pool Age counts years after 1857. Wald test for equality of the coefficients on pool*chain stitch and pool*lockstitch. Standard errors are clustered at the subclass level. ** significant at 1 percent, * significant at 5 percent. 


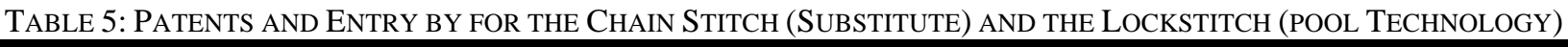

\begin{tabular}{|c|c|c|c|c|c|c|c|c|c|c|}
\hline \multirow[b]{3}{*}{ Years } & \multirow{2}{*}{\multicolumn{2}{|c|}{ License Fees }} & \multicolumn{4}{|c|}{ Patent Grants } & \multicolumn{4}{|c|}{ New Firms Entering the Industry } \\
\hline & & & \multicolumn{2}{|c|}{ All } & \multicolumn{2}{|c|}{ Granted to Licensees } & \multicolumn{2}{|c|}{ All } & \multicolumn{2}{|c|}{ Licensees } \\
\hline & Outsider & Member & Chain stitch & Lockstitch & Chain stitch & Lockstitch & Chain stitch & Lockstitch & Chain stitch & Lockstitch \\
\hline $1849-52$ & $\$ 0$ & $\$ 0$ & 11 & 6 & 1 & 0 & 3 & 8 & 0 & 2 \\
\hline $1853-56$ & $\$ 25$ & $\$ 25$ & 19 & 21 & 3 & 1 & 5 & 12 & 0 & 4 \\
\hline $1857-60$ & $\$ 15$ & $\$ 5$ & 107 & 63 & 3 & 5 & 25 & 9 & 2 & 5 \\
\hline $1861-67$ & $\$ 7$ & $\$ 1$ & 42 & 60 & 5 & 7 & 13 & 8 & 4 & 6 \\
\hline $1868-70$ & $\$ 5$ & $\$ 0$ & 21 & 57 & 1 & 7 & 8 & 4 & 2 & 3 \\
\hline $1871-76$ & $\$ 3$ & $\$ 0$ & 22 & 100 & 1 & 10 & 5 & 12 & 2 & 2 \\
\hline $1877-85$ & $\$ 0$ & $\$ 0$ & 35 & 192 & 0 & 14 & 2 & 25 & 0 & 0 \\
\hline
\end{tabular}

Notes: Chain stitch patents cover the substitute for the pool technology; these are patents are in USPTO subclasses 112:173-175 and 112:197-202. Lockstitch patents cover the pool technology; these are patents are in subclasses 112:181-196. Data on all patents from the USPTO Patent Full-Text and Image Database.

Chain stitch patents are in USPTO subclasses 112:173-175 and 112:197-202, lockstitch patents are in subclasses 112:181-196. Three patents that were listed both as chain and lockstitch inventions (21089, 18880, and 89093), are included in both categories. Data on licensees and firm entry from Cooper (1976); data on stitch types from Knight (1877), Cooper (1976), Bays (2007), and the Smithsonian Archives. 
Figure 1 - Share of Sewing-Machine Patents in ALl Patents:

UNITED STATES VERSUS BRITAIN

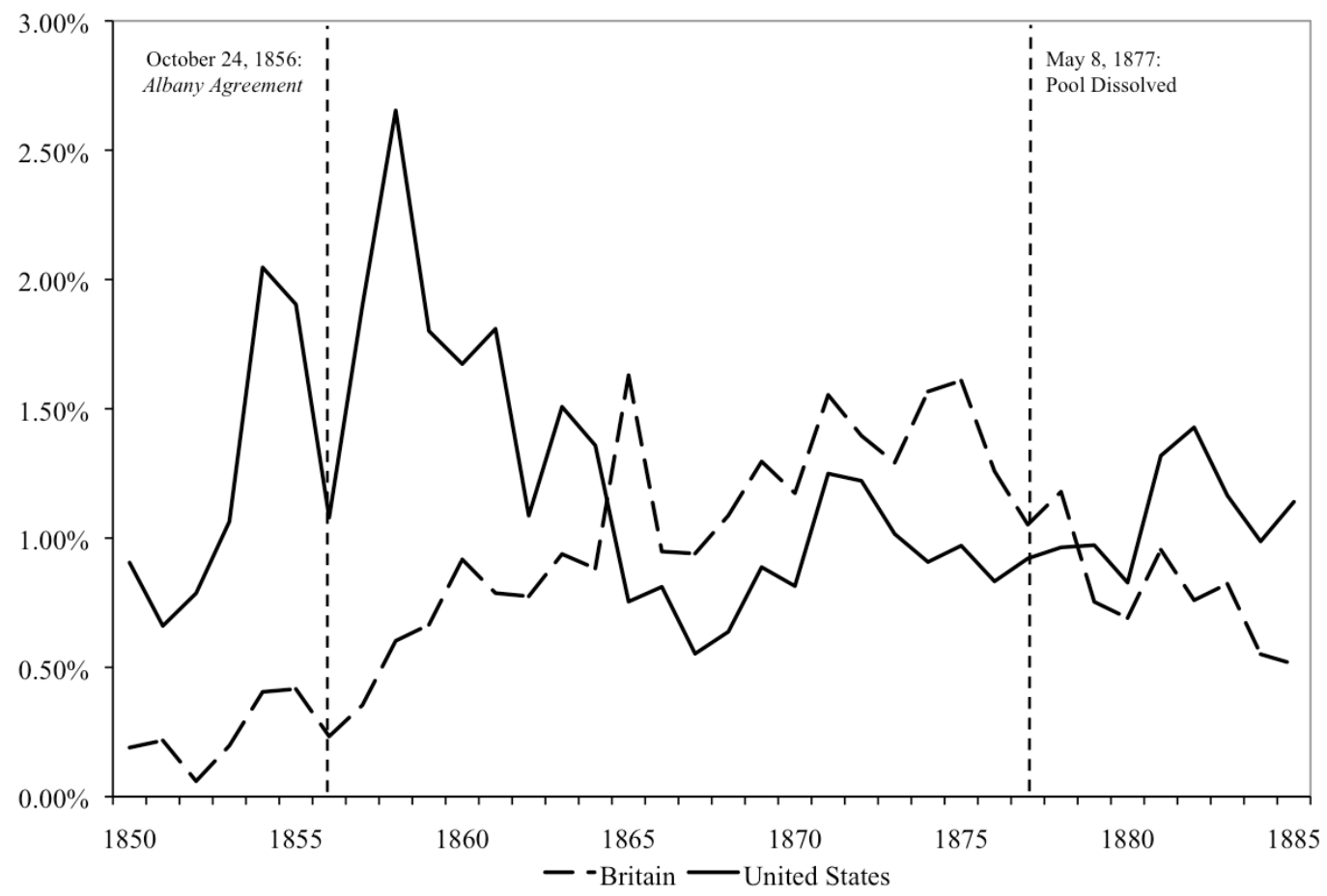

Notes: U.S. patents granted in USPTO main class 112 Sewing; British patents from A Cradle of Inventions:

British Patents from 1617 to 1894 . Data are for substantive inventions only, excluding patents for attachments, tables and stands.

\section{Figure 2 - Market SHARES of PoOl MEMBers AND LicenseEs}

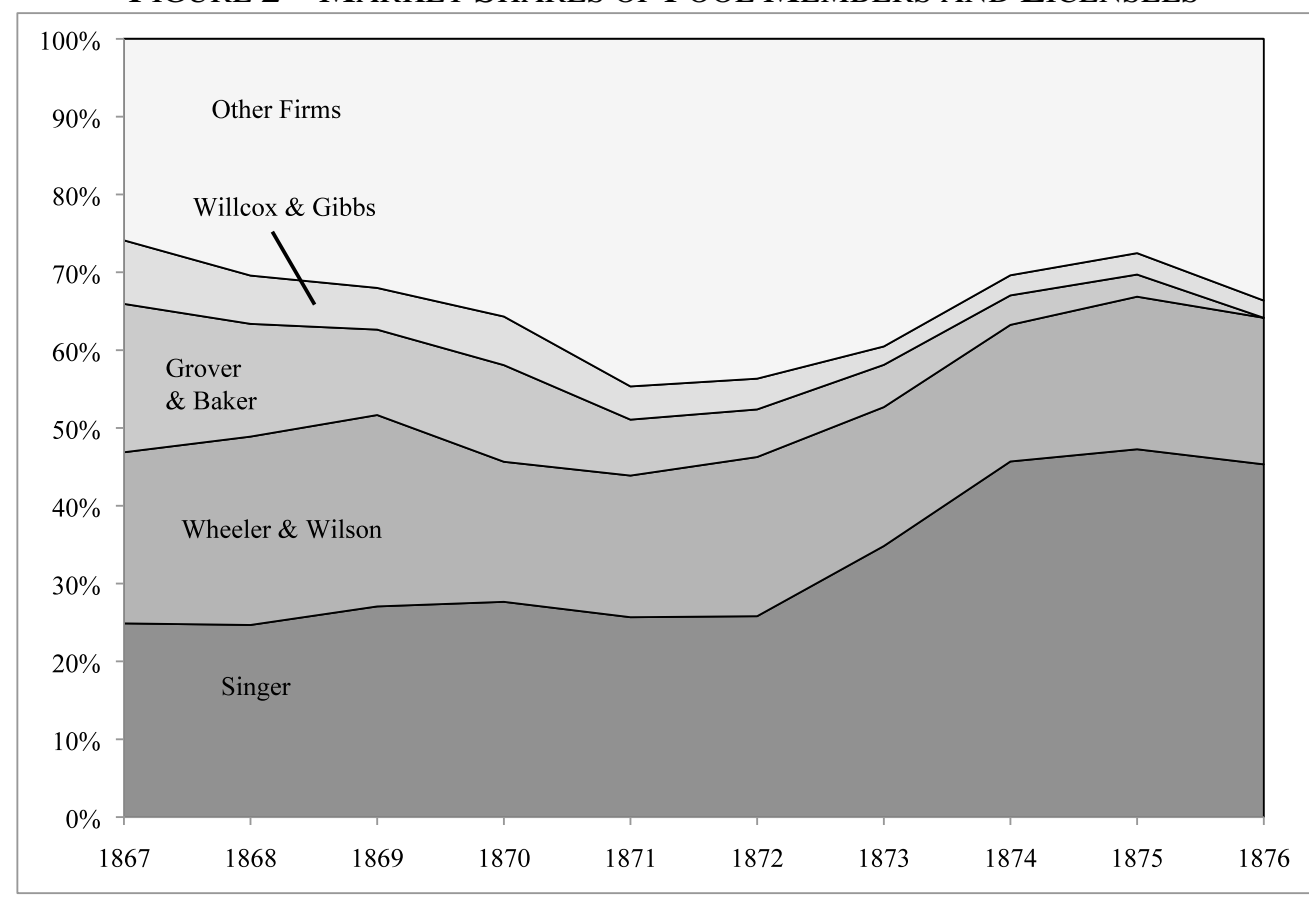

Notes: Data on market shares for licensees of the pool from Cooper (1976); production data for Wheeler \& Wilson are missing in 1868 - we include the average of sales for 1867 and 1869. Grover \& Baker exited the industry in 1875 . 
Figure 3 - Lockstitch And Chain stitch Patents Per Year

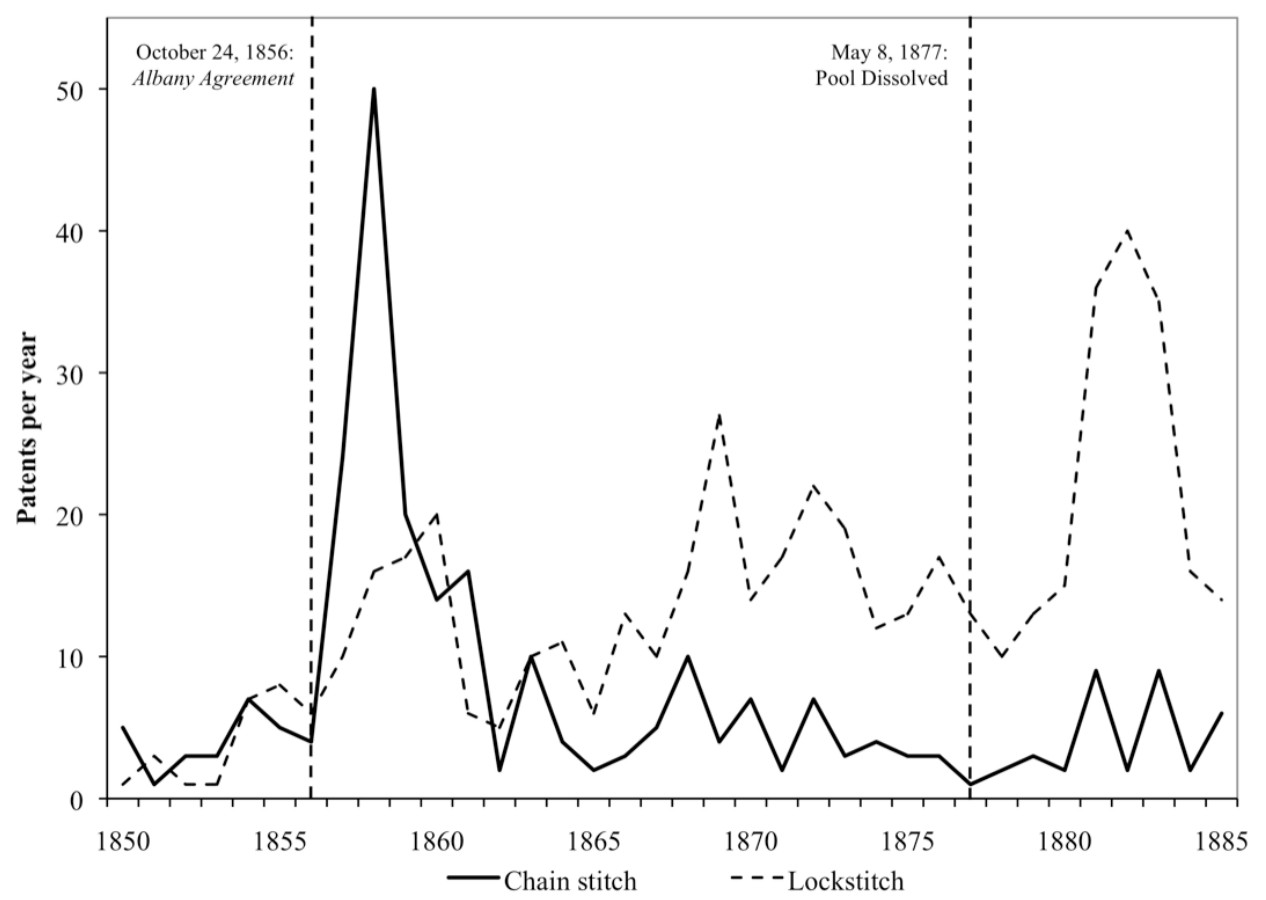

Notes: Patents granted in subclasses of lockstitch and chain stitch inventions per year from the USPTO Patent Full-Text and Image Database. Lockstitch subclasses are 112: 181 to 196; chain stitch subclasses are 112 : 173 to 175 and 112: 197 to 202.

\section{Figure 4 - Year-Specific Estimates of the PoOl's EfFect on Chain Stitch Patents}

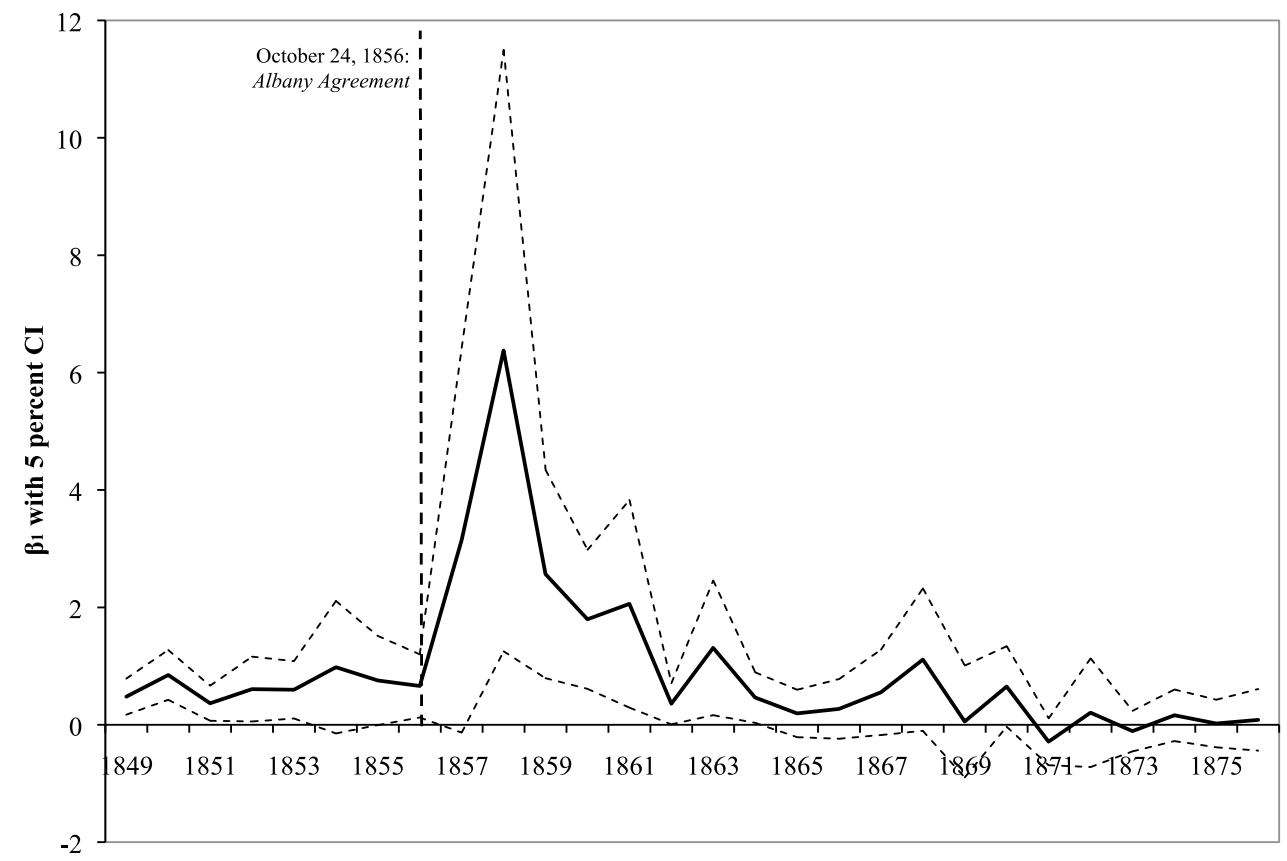

Notes: Annual estimates of $\beta_{2 t}$ in the OLS regression Patents ct $=\alpha+\beta_{1 t}$ Pool $_{t} *$ Chain stitch $_{c}+\beta_{2 t}$ Pool $_{\mathrm{t}}$ $*$ Lockstitch $_{c}+\delta_{t}+f_{c}$. To control for pre-trends in patenting, the variable Pool is set to 1 starting in $1849 ; \delta_{t}$ are year fixed-effects and $f_{c}$ are subclass fixed-effects. 


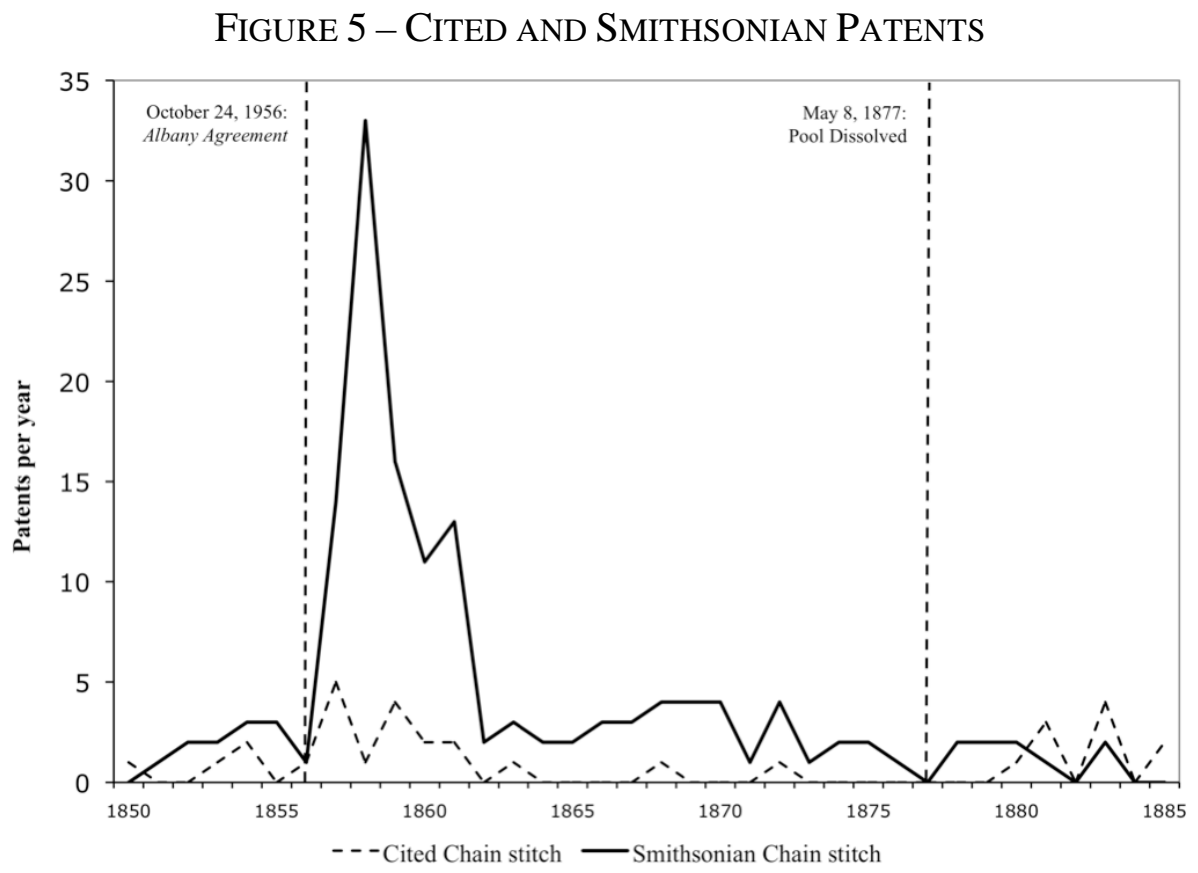

Notes: Citations are captured through an automated full text search of U.S. patents in class 112 from 1920 to 1974 for references to US patents between 1845 and 1885 in the same class. The algorithm identifies 600 potential citations; a hand-check removes 145 erroneous citations that are typically based on the random occurrence of a patent number in the full text of a patent. Citations for 1975 to 2002 are from the NBER patent data set (Hall, Jaffe and Trajtenberg, 2001). Smithsonian patents were selected by Smithsonian curators as significant inventions (Cooper, 1976).

\section{FigURE 6 - ENTRANTS By STITCH TYPE}

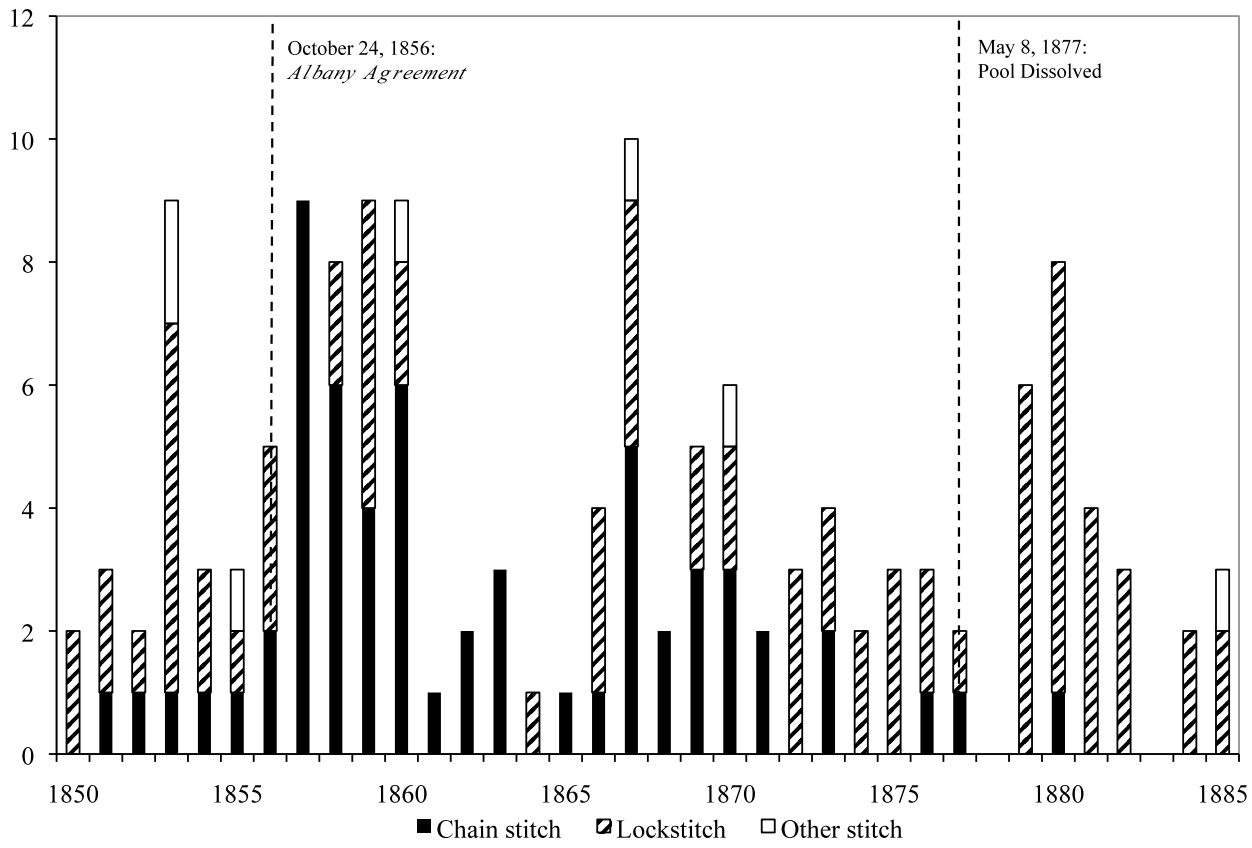

Notes: Entrants to the sewing machine industry are listed in Cooper (1976); stitch type are matched to firms based on guide books for sewing machine collectors, contemporary atlases of technology, and archival records at the Smithsonian Institution (Knight 1877, Bays 2007, and the Smithsonian Historical Archives). "Other stitch" includes specialized stitches for buttonholes and leather. 